\title{
ANTS FROM THE CRETACEOUS AND EOCENE AMBER OF NORTH AMERICA*
}

\author{
BY EDWARD O. WILSON \\ Museum of Comparative Zoology, Harvard University \\ Cambridge, Massachusetts 02138, U.S.A.
}

The discovery of Sphecomyrma freyi in amber from New Jersey disclosed the existence of an extinct subfamily of ants (Sphecomyrminae) intermediate in some traits between modern ants and nonsocial wasps and dating as far back as the lower part of the Upper Cretaceous (Wilson et al., 1967a, b). Subsequently Dlussky $(1975,1983)$ described a series of new genera from the Upper Cretaceous of the Taymyr Peninsula (extreme north-central Siberia), southern Kazakh S.S.R., and the Magadan region of extreme eastern Siberia. Among the various specimens assigned to these taxa (the genera are Archaeopone, Armania, Armaniella, Cretomyrma, Cretopone, Dolichomyrma, Paleomyrmex, Petropone, Poneropterus, and Pseudarmania), the ones well enough preserved to disclose subfamily-level diagnostic characters appear to fall within the Sphecomyrminae. Indeed it is difficult to find sound reasons for separating most of them from Sphecomyrma, providing we limit ourselves to the same criteria applied to contemporary genera and tribes. There seems to be little justification for placing them in a separate family, the Armaniidae, as suggested by Dlussky.

If this interpretation of the Russian material is correct, we have established that the most primitive known group of ants, the Sphecomyrminae, lived over much of the northern hemisphere during middle and late Cretaceous times. Other discoveries have revealed that by Eocene times, some $\mathbf{5 0}$ million years later, higher forms of ants had come into existence, but the evidence remains very scanty and ambiguous. Eomyrmex guchengziensis, described from amber in the Eocene coal beds of Fushun, Manchuria, appears from the description and illustrations to be a relatively primitive ponerine with traits reminiscent of the Sphecomyrminae (Hong et al., 1974). Because of its possibly intermediate status, a further study of the single worker would be a valuable exercise. The giant Eoponera

*Manuscript received by the editor March 16, 1985. 
berryi of the Tennessee Eocene, long considered to be a ponerine, was recently placed in the horntail family Pseudosiricidae by Smith (1978) and by Rasnitsyn (1980). F. M. Carpenter, the original describer of this species, concurs with this placement (Carpenter, personal communication). Finally, a winged queen found in the midEocene oil shales of Messel, Germany, has been placed in either the Dolichoderinae or Formicinae by Gahl and Maschwitz (1977). This is a reasonable approximation, but the specimen is so poorly preserved that an alternative subfamily assignment-even to some as yet unrecognized, extinct group-cannot be excluded.

It is clear, then, that in order to understand the key events of ant evolution the most crucial time frame in which to study fossils is the Upper Cretaceous to Middle Eocene. I report here two recent important finds: the first ants from the Cretaceous amber of Canada, representing a new species of Sphecomyrma; and a small sample of workers from the mid-Eocene amber of Arkansas, representing three of the most advanced subfamilies of ants (Myrmicinae, Dolichoderinae, Formicinae).

\section{Sphecomyrma canadensis, new species}

(Figs. 1, 2)

Diagnosis. Closely resembling $S$. freyi of the New Jersey amber (Magothy Formation, mid-Cretaceous) in most of its visible traits, differing in its smaller size (Head Width of holotype $0.66 \mathrm{~mm}$ as opposed to $1.00 \mathrm{~mm}$ in freyi), somewhat more robust alitrunk, and proportionately shorter third funicular segment (which is about as long as the second funicular segment, as opposed to slightly more than twice as long in freyi).

Holotype worker. Head Width $0.66 \mathrm{~mm}$, Head Length 0.66 $\mathrm{mm}$, Scape Length $0.50 \mathrm{~mm}$, length of alitrunk $1.32 \mathrm{~mm}$. A relatively well-preserved worker collected in situ in the Cretaceous "Canadian amber" deposits near Medicine Hat, Alberta. J. F. McAlpine, CAS 330, deposited in the Biosystematics Research Institute, Ottawa, Canada.

Paratype worker. Length of alitrunk $1.57 \mathrm{~mm}$. A poorly preserved worker in the Medicine Hat amber provisionally placed in the same species as the holotype. J. E. H. Martin and J. F. McAlpine, CAS 205, deposited in the Biosystematics Research Institute, Ottawa, Canada. 

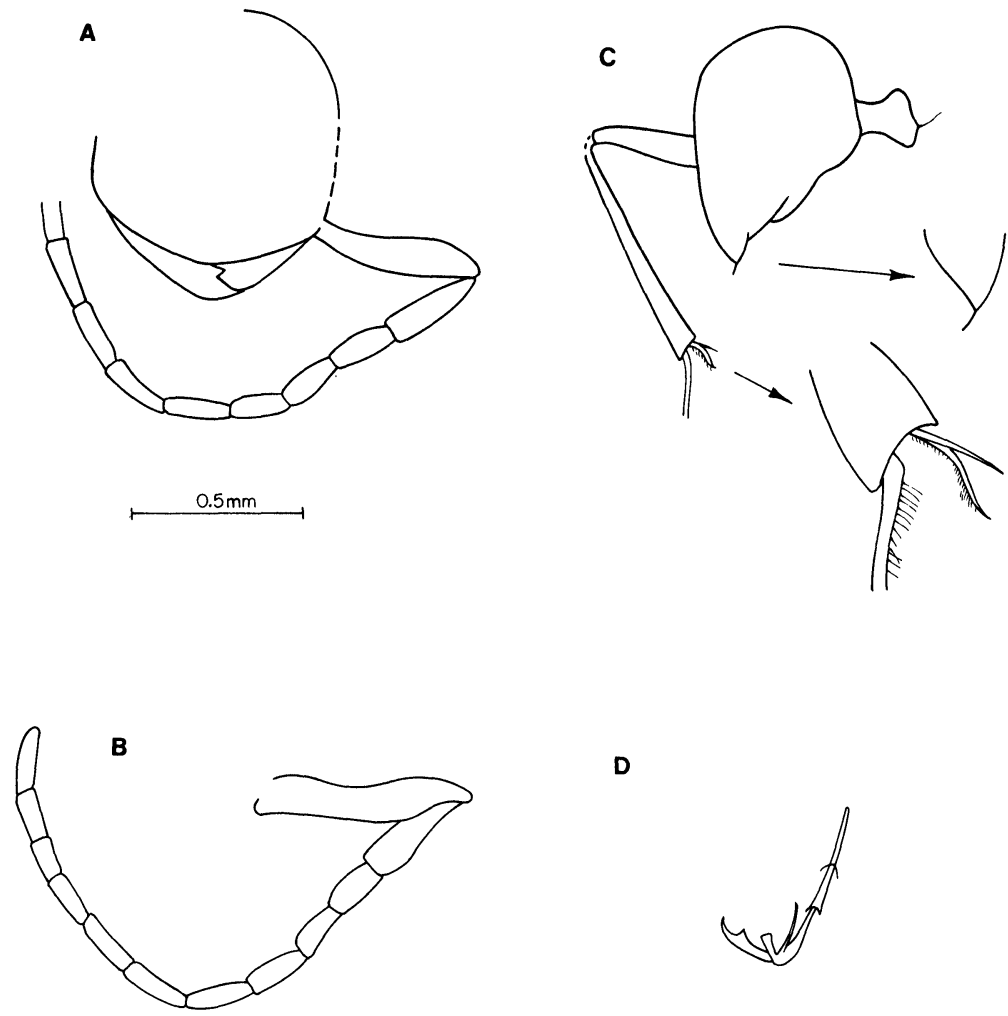

D

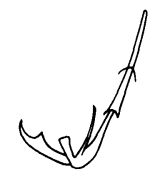

Fig. 1. Sphecomyrma canadensis, holotype worker: A, frontal view of head; B, left antenna, dorsal view; $\mathbf{C}$, gaster, petiole, and left rear leg, with enlarged views of the rear-leg tibial comb and spur and tip of abdomen (showing the extruded sting); D, left front tarsus.

These are the first ants recorded from the Canadian amber, despite the fact that thousands of pieces containing large numbers of insects of diverse orders have been processed since the late nineteenth century (Carpenter et al., 1937; Rice, 1980). The holotype (and by inference the paratype) is so close to $S$. freyi in key characters that it can be placed with certainty in the Sphecomyrminae and with reasonable confidence in Sphecomyrma, providing we use the same anatomical standards by which the modern subfamilies and genera of ants are distinguished. The resemblance is well marked, 

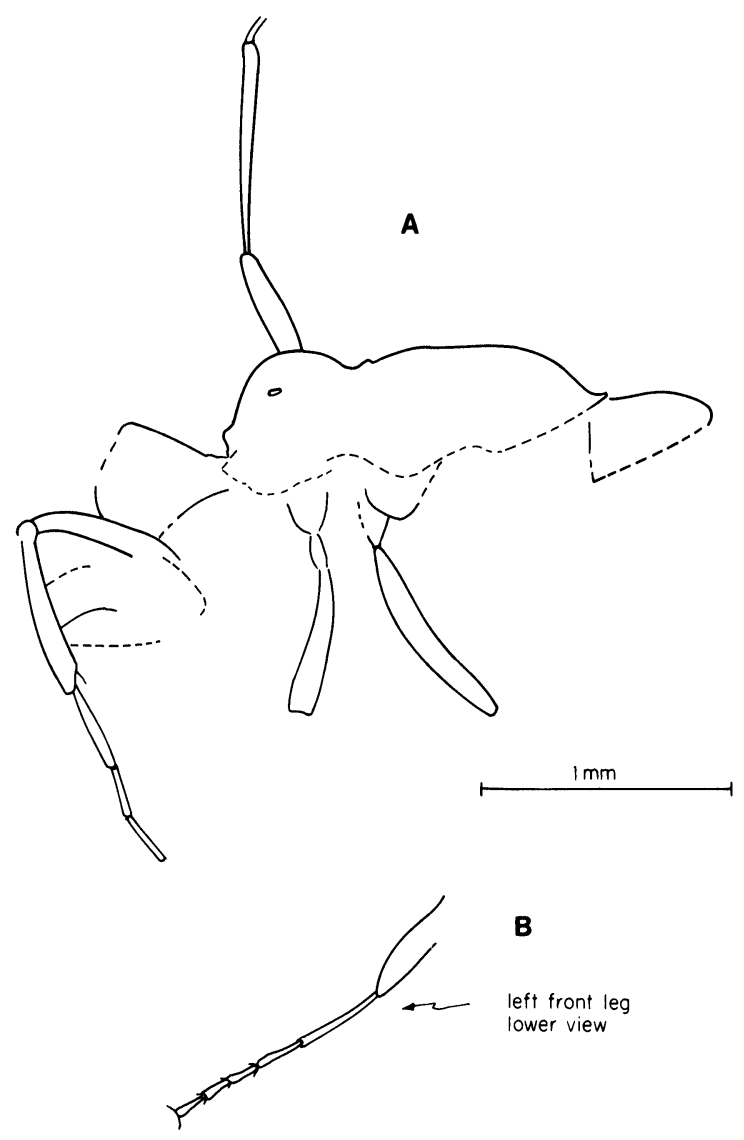

Fig. 2. Sphecomyrma canadensis, paratype worker: A, part of right side of body and head; B, left front leg.

for example, in the overall body form, including especially the distinctive petiole and head; in the unique short, 2-toothed mandibles; in the equally peculiar antenna, with its proportionately short scape and long, flexuous funiculus; and in the well-developed secondary median claw of the tarsus.

During late Cretaceous times the Alberta locality was close to the midpoint between New Jersey and Magadan, the easternmost of the Russian fossil sites. Thus the discovery of the Canadian specimens 
contributes new evidence that the most primitive known ant subfamily, the Sphecomyrminae, was widespread through the northern half of the world during the latter half of the Cretaceous Period.

\section{Eocenidris, new genus}

Diagnosis (worker). An Eocene myrmicine genus distinguished from all other known genera by the following combination of worker traits: very small size; relatively narrow mandibles with oblique masticatory border bearing 6 irregularly shaped teeth; smoothly and strongly convex promesonotum apparently undivided by transverse sutures; propodeum armed with short, stout spines; and incrassate femora and tibiae.

Type species: Eocenidris crassa.

\section{Eocenidris crassa, new species}

(Fig. 3)

Diagnosis (worker). Distinguished from other known ants by the combined traits just cited in the generic diagnosis.

Holotype worker. Head Width $0.40 \mathrm{~mm}$; length of alitrunk from the anterior edge of pronotal collar to posterior edge of propodeal flange, $0.50 \mathrm{~mm}$. Other visible features as shown in Fig. 3. The antennae and eyes are either missing or positioned in a way so as not to be made visible without endangering the specimen through fragmentation. Similarly, the posterior part of the abdomen could not be studied. In amber of the Middle Eocene (Claiborne) of Malvern, Arkansas. Collected by R. H. Mapes (see Saunders et al., 1974). Deposited in the Museum of Comparative Zoology, Harvard University.

Eocenidris crassa is a typical myrmicine, possessing a set of traits that are advanced relative to those of Agraecomyrmex of the Baltic amber, the modern genera Hylomyrma and Myrmica, and other Myrmicinae considered primitive. Its existence demonstrates conclusively that a substantial amount of evolution had occurred within the subfamily, hence within the ants as a whole, by the middle of the Eocene.

$E$. crassa superficially resembles the species of the modern Neotropical genus Oxyepoecus, which are in some cases inquilines of Pheidole and Solenopsis, but it lacks ventral processes on either the 

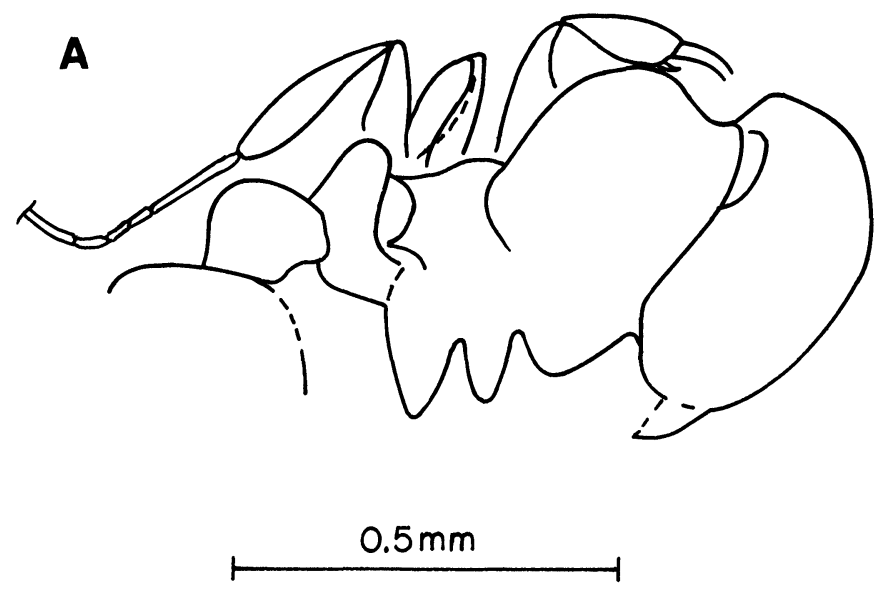

B
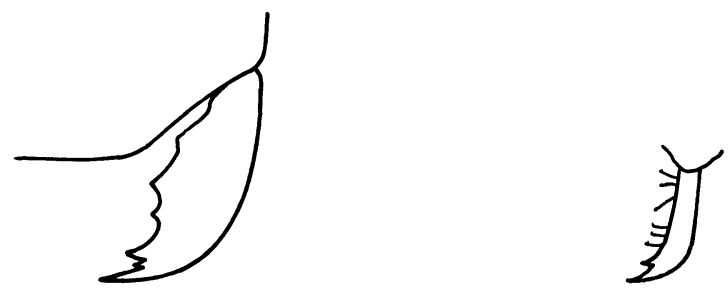

C

Fig. 3. Eocenidris crassa, holotype worker: A, oblique-dorsal view of head and part of body; B, left mandible and part of clypeus, full-face view; $\mathbf{C}$, left mandible with masticatory border facing observer, revealing the row of vertical bristles on the inner surface.

petiole or postpetiole and possesses more uniform and numerous mandibular teeth (6 as opposed to 4 in Oxyepoecus). It also bears a general resemblance to some of the New World species of Erebomyrma (eidmanni, longi, nevermanni, and urichi), including its possession of stiff bristles along the inner mandibular surface and incrassate femora and tibia. It is easily distinguished from these 
ants, however, by its more convex promesonotum and more numerous and less evenly distributed mandibular teeth (4 in all Erebomyrma and 5 in the Old World species of the closely related genus Oligomyrmex).

Iridomyrmex mapesi, new species

(Figs. 4, 5)

Diagnosis (worker). An Eocene species tentatively assigned to Iridomyrmex on the basis of the overall habitus, antennal form, and structure of the mandibles, which fall within the limits of the living and fossil species placed within that genus. The preservation of the single type is not good enough to make a detailed comparison with all of the previously recognized forms of Iridomyrmex, but the following minimal characterization is possible. The worker of mapesi is larger and possesses fewer mandibular teeth than the living New World species and I. hispaniolae and I. humiloides of the Miocene Dominican amber. In these traits mapesi falls within the range of some of the contemporary members of the Indo-Australian calvus, cordatus, and rufoniger groups. Hence, in a purely technical sense it is not possible to separate mapesi from all other known ants, but on the combined basis of its age, geographical location, and morphology this form can be safely treated as a distinct species.

Holotype worker. Head Width $1.06 \mathrm{~mm}$, Head Length $1.1 \mathrm{~mm}$ (measurable only to the nearest $0.1 \mathrm{~mm}$ ), Eye Length $0.11 \mathrm{~mm}$, Pronotal Width $0.62 \mathrm{~mm}$. Other visible details as illustrated in Figs. 4 and 5. Deposited in the Museum of Comparative Zoology.

The species is named in honor of Royal $\mathrm{H}$. Mapes, the discoverer of the Arkansas amber, who also collected the type specimen.

I. mapesi is the oldest verifiable record of the subfamily Dolichoderinae. The following note may be of additional, ecological significance: a small segment of leafy liverwort (Hepaticae) is embedded close to the head of the I. mapesi worker. According to Alice F. and Rolla M. Tryon, who kindly identified the fragment, the presence of these plants indicates a mesic habitat, presumably either swampland or mesic forest.

\section{Protrechina, new genus}

Diagnosis (worker). A small Eocene formicine close to Paratrechina in habitus, differing from that genus in its lack of a circlet 

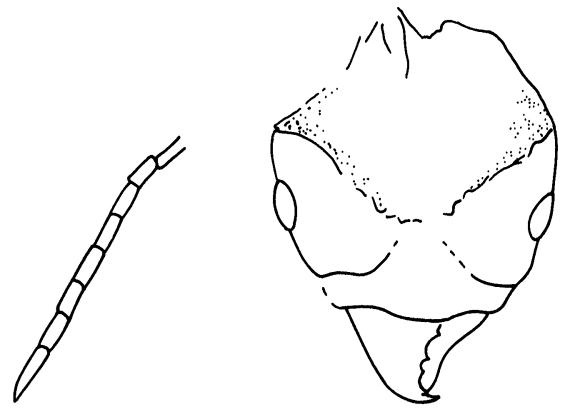

A
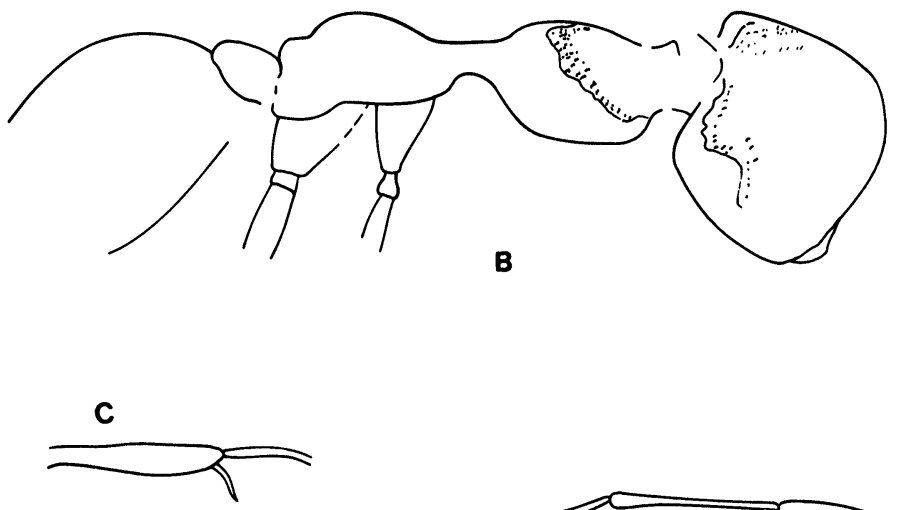

D

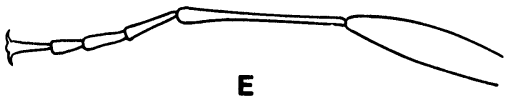

Fig. 4. Iridomyrmex mapesi, holotype worker: $\mathbf{A}$, frontal view of head and part of right antenna; B, right side of part of head and body; C, left hind tibia and metatarsus; D, left front femur and tibia; E, middle right tibia and tarsus.

of hairs surrounding the acidopore (Paratrechina and most other formicine genera possess the circlet) and in the absence of the upraised paired bristles on the alitrunk (possessed by Paratrechina and some species of Acantholepis and Brachymyrmex).

Type species: Protrechina carpenteri. 

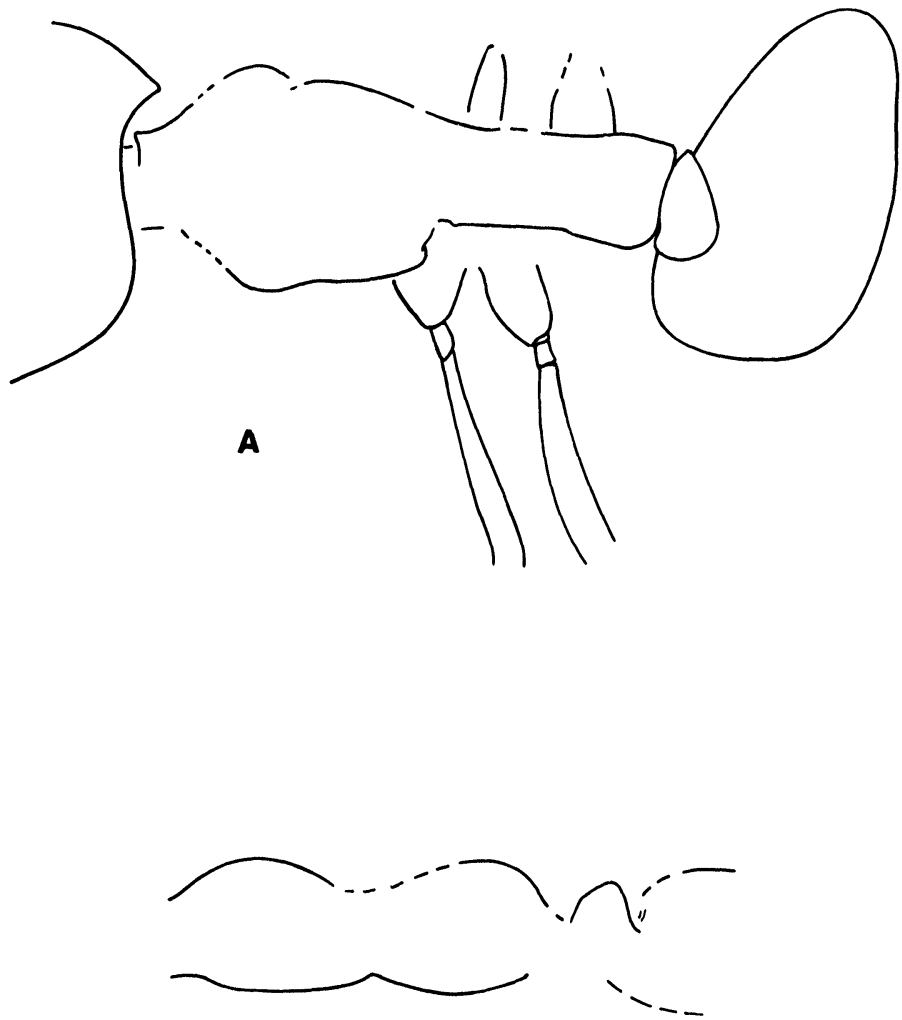

B

Fig. 5. Iridomyrmex mapesi, holotype: A, dorsal view of part of head and body; $B$, left side of alitrunk and petiole.

Protrechina carpenteri, new species

(Fig. 6)

Diagnosis (worker). Distinguished from all other known formicine ants by the characteristics just cited for the genus Protrechina.

Holotype worker. Head Width $0.23 \mathrm{~mm}$, Scape Length 0.48 $\mathrm{mm}$, Pronotal Width $0.23 \mathrm{~mm}$. Ocelli absent. Mandibles folded, evidently short, and hidden from view. Body surface smooth to weakly shagreened, and feebly shining. Upper surface of head and 

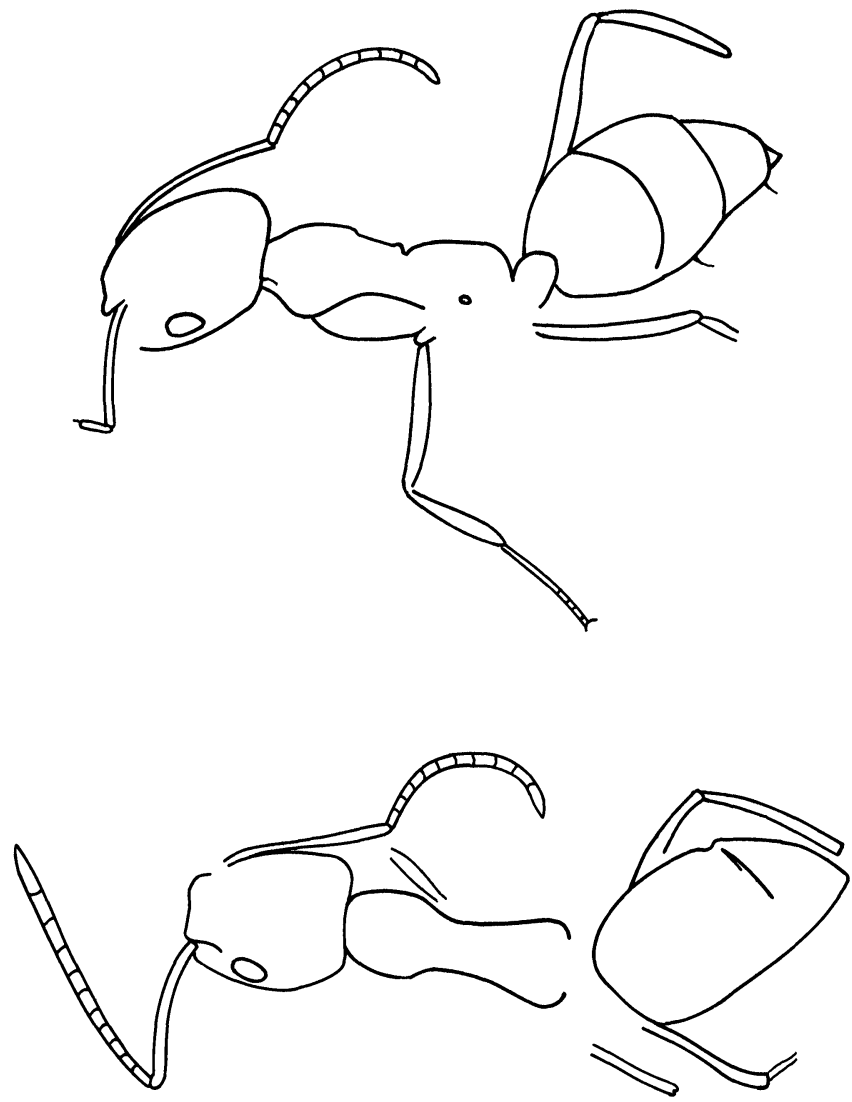

Fig. 6. Protrechina carpenteri, holotype: two views of entire body.

body devoid of hairs. In amber of the Middle Eocene (Claiborne) of Malvern, Arkansas. Collected by R. H. Mapes (see Saunders et al., 1974). Deposited in the Museum of Comparative Zoology.

The species is named for Frank M. Carpenter in recognition of his pioneering work on the fossil ants of North America.

Two comments on the generic diagnosis are required. First, the conical shape of the last gastric segment as seen from two obliquely dorsal views leaves little doubt that the Protrechina carpenteri holotype possessed an acidopore, the most distinctive trait characterizing the Formicinae as a whole. Unfortunately, while grinding the 
amber piece along a new plane in order to see the opening of the acidopore, I shattered and lost the rear part of the abdomen before this opening came into view. Hence I cannot be certain that the ant possessed a typically circular formicine acidopore. Additionally, the absence of a circlet of hairs at the tip of the abdomen and paired bristles on the alitrunk, on which the generic diagnosis rests, could be the result of postmortem deterioration. However, I doubt that such is the case, because the body form as a whole and the entire dorsal cuticular surface were preserved in excellent shape, without the kind of distortion and rupturing usually accompanying severe decay in amber specimens. Also, at least two well-preserved hairs were present on the ventral surface of the gaster, as depicted in Fig. 6 .

To ascertain the status of Protrechina I surveyed representatives of all of the living genera of Formicinae with reference to the two characters in pilosity. In only two genera, Oecophylla and Camponotus (and only in a few species of the latter), is the circlet of acidopore hairs lacking. Conversely, only some of the species of Acantholepis and Brachymyrmex share the Paratrechina trait of coarse paired setae on the alitrunk dorsum. Thus Protrechina is not unique among the Formicinae in its possession of the two character states that distinguish it from Paratrechina.

Protrechina carpenteri, if I have interpreted its morphological features correctly, is the first member of the Formicinae recorded from a definitely dated Eocene deposit.

\section{SUMMARY}

(1) The first ants from the Canadian amber are described as Sphecomyrma canadensis, providing a record of the primitive Cretaceous subfamily Sphecomyrminae geographically intermediate between the New Jersey and Siberian collections recorded earlier.

(2) The first specimens of Eocene ants definitely assignable to higher subfamilies have been discovered in amber from Malvern, Arkansas: Eocenidris crassa (Myrmicinae), Iridomyrmex mapesi (Dolichoderinae), and Protrechina carpenteri (Formicinae).

\section{ACKNOWLEDGEMENTS}

I am grateful to Barry Bolton, William L. Brown, Jr., and Frank M. Carpenter for invaluable advice and assistance given during this study, to James F. McAlpine for supplying the Canadian amber 
specimens, and to Royal $H$. Mapes for supplying the Arkansas amber specimens. The research was supported in part by National Science Foundation grant no. BSR 81-19350.

\section{REFERENCES}

Carpenter, F. M., J. W. Folsom, E. O. Essig, A. L. Kinsey, C. T. Brues, M. W. BoEsel, AND H. E. Ewing.

1937. Insects and arachnids from Canadian amber. Univ. Toronto Studies, Geol. Ser., 40: 7-62.

DLussky, G. M.

1975. Formicidae. In Rasnitsyn, A. P, Hymenoptera Apocrita of the Mesozoic. Trans. Paleont. Inst., Acad. Sci. USSR, 147: 115-121. (In Russian).

1983. A new family of Upper Cretaceous Hymenoptera: An "intermediate link" between the ants and the scolioids. Paleont. J., 17: 65-78. (In Russian; translated into English by Scripta Publishing Company.)

Gahl, H. AND U. MaSChWITZ.

1977. Eine Ameise aus dem Mittel-Eozan von Messel bei Darmstadt (Hessen). Geol. Jahrb. Hessen, 105: 69-73.

Hong, Y.-C., T.-C. Yang, S.-T. Wang, S.-E. Wang, Y.-K. Li, M.-R. Sun, H.-C. SUn, AND N.-C. TU.

1974. Stratigraphy and paleontology of Fushun Coal-field, Liaoning Province. Acta Geol. Sinica, 1974(2): 113-149, 8 pls.

Rasnitsyn, A. P.

1980. Origin and evolution of the Hymenoptera. Trudy Paleontol. Inst., Acad. Sci., USSR, 174: 1-190. (In Russian).

RICE, P. C.

1980. Amber: The Golden Gem of the Ages. Van Nostrand Reinhold, New York.

Saunders, W. B., R. H. Mapes, F. M. Carpenter, and W. C. Elsik.

1974. Fossiliferous amber from the Eocene (Claiborne) of the Gulf Coastal Plain. Geol. Soc. Amer. Bull., 85: 979-984.

SMITH, D. R.

1978. Pseudosiricidae. Hymenoptera Catalogus, 14: 35.

Wilson, E. O., F. M. CARPenter, AND W. L. Brown.

1967a. The first Mesozoic ants. Science, 157: 1038-1040.

1967b. The first Mesozoic ants, with the description of a new subfamily. Psyche, 74: 1-19. 

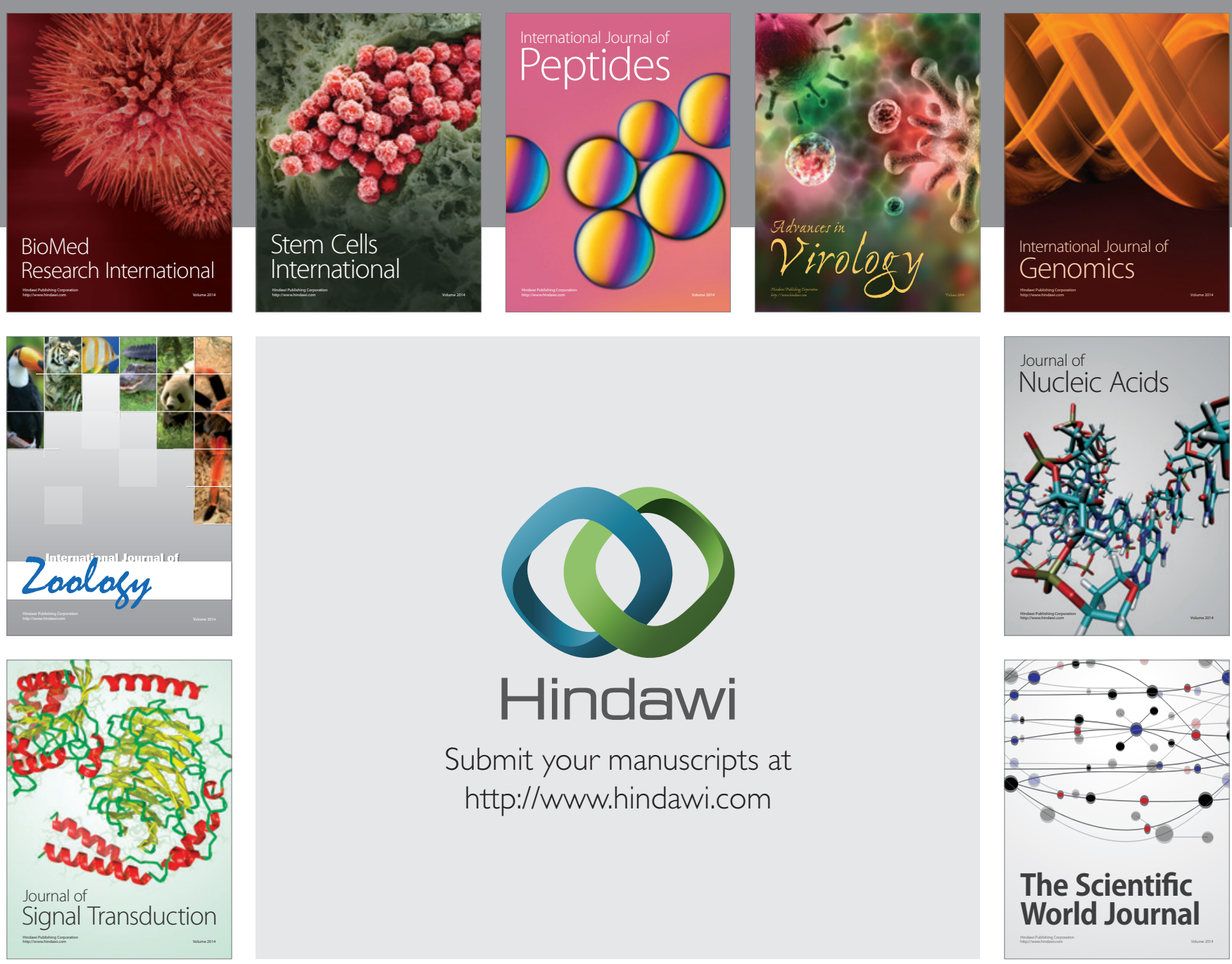

Submit your manuscripts at

http://www.hindawi.com
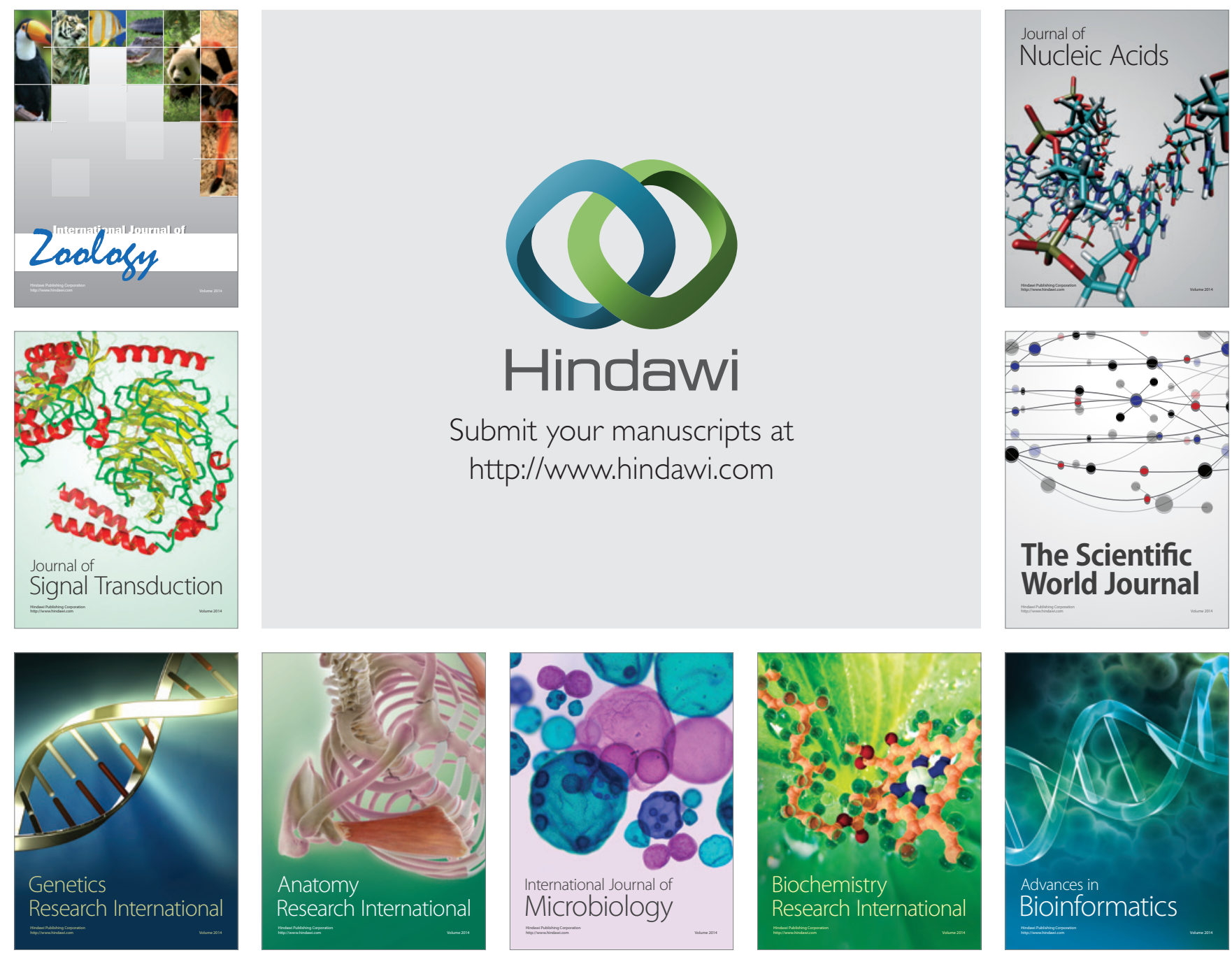

The Scientific World Journal
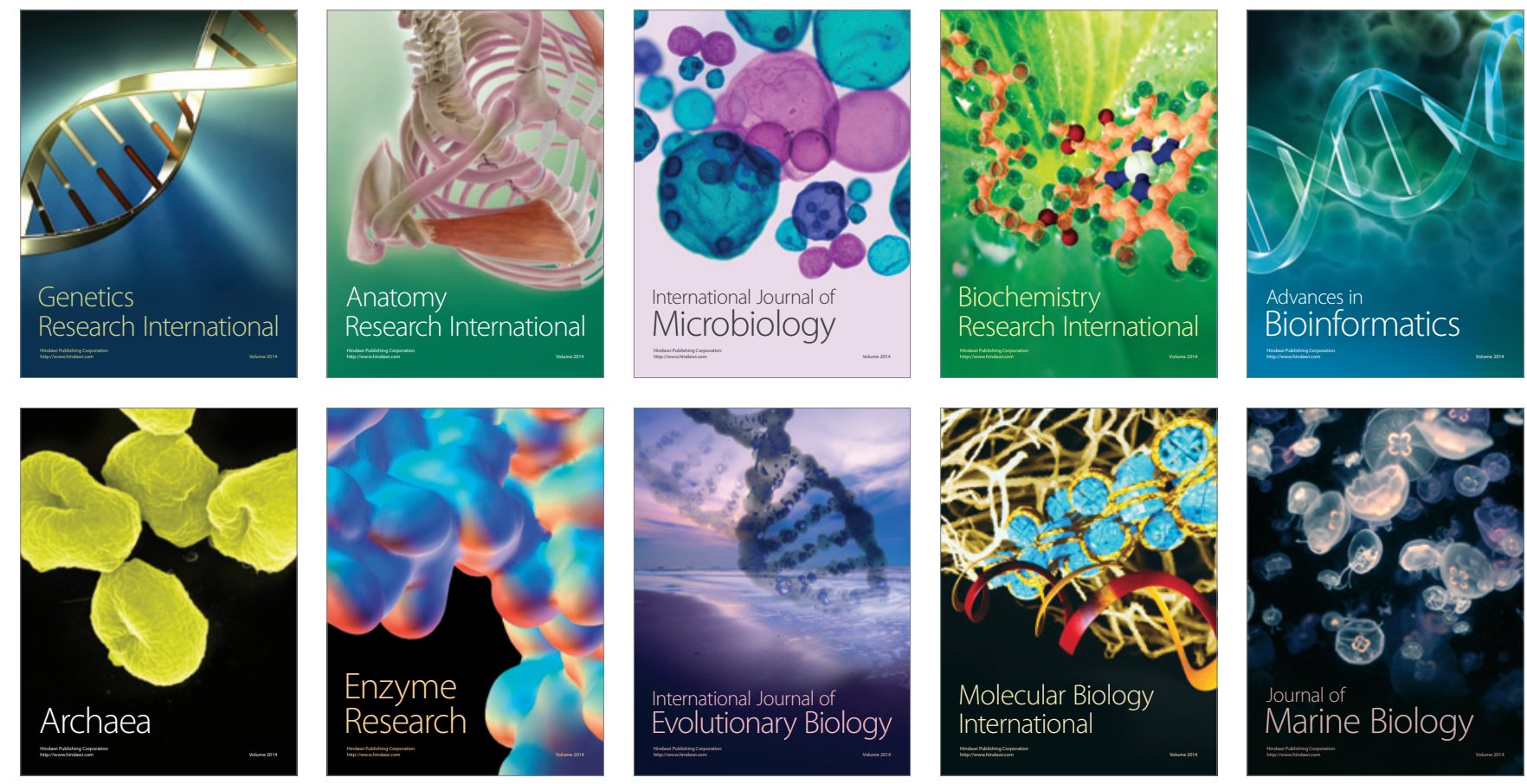